\title{
Streptococcus marimammalium sp. nov., isolated from seals
}

Correspondence

Matthew D. Collins

m.d.collins@reading.ac.uk

\author{
Paul A. Lawson, ${ }^{1}$ Geoffrey Foster, ${ }^{2}$ Enevold Falsen ${ }^{3}$ \\ and Matthew D. Collins ${ }^{1}$
}

${ }^{1}$ School of Food Biosciences, University of Reading, PO Box 226, Reading RG6 6AP, UK

${ }^{2}$ SAC Veterinary Services, Drummondhill, Stratherrick Road, Inverness IV2 4JZ, UK

${ }^{3}$ Culture Collection, Department of Clinical Bacteriology, University of Göteborg, Guldhedsg 10, S-413 46 Göteborg, Sweden
The genus Streptococcus embraces a phenotypically diverse group of catalase-negative, Gram-positive, coccus-shaped organisms. In recent years the genus has undergone considerable expansion with a plethora of novel species described, especially from human and animal sources (Facklam, 2002). Although the genus now accommodates more than 60 species, relatively few of these streptococcal species have been recovered from marine animals. Indeed only three species, Streptococcus phocae (Skaar et al., 1994) and Streptococcus halichoeri (Lawson et al., 2004) from seals and Streptococcus iniae recovered from freshwater dolphins and subsequently found in aquacultures of fish and from humans (Pier \& Madin, 1976; Weinstein et al., 1997), have originated from marine mammals. During the course of a study of taxonomically problematic, catalase-negative, Gram-positive cocci from marine mammals we have characterized two novel Streptococcus-like isolates from a common seal and a grey seal. Based on the results of a polyphasic taxonomic study, we describe a novel species, Streptococcus marimammalium sp. nov., from marine mammals.

Two bacterial isolates were recovered from different species

The GenBank/EMBL/DDBJ accession number for the 16S rRNA gene sequence of strain CCUG $48494^{\top}$ is AJ634751. of seal. Strain M54/01/1 ${ }^{\mathrm{T}}$ was recovered from a grey seal (Halichoerus grypus) and strain M529/97/1 (=CCUG 48934) was isolated from the lung of a common seal (Phoca vitulina) following post-mortem in Inverness, Scotland. The unidentified strains were cultured on Columbia agar base supplemented with $5 \%$ sheep blood at $37^{\circ} \mathrm{C}$ under capnophilic conditions. Organisms were characterized biochemically using the API Rapid ID 32Strep, API 20Strep and API ZYM systems according to the manufacturer's instructions (API bioMérieux). Lancefield serological grouping was determined by using the Streptex (Remell Europe) test system. To assess the overall phenotypic resemblance of the new isolates and related species, a comparative analysis of whole-cell protein profiles by SDS-PAGE was performed. PAGE analysis of whole-cell proteins was performed as described by Pot et al. (1994) and Vandamme et al. (1998). For densitometric analysis, normalization and interpretation of protein patterns, the GCW 3.0 software package (Applied Maths) was used. Similarity between all pairs of traces was expressed by using the Pearson product moment correlation coefficient converted for convenience to a percentage similarity. The DNA $\mathrm{G}+\mathrm{C}$ content of strain M54/01/1 ${ }^{\mathrm{T}}$ was determined by HPLC according to the method of Mesbah et al. (1989). For phylogenetic analysis, 16S rRNA genes were amplified by PCR and sequenced 
directly using a Taq dye-Deoxy terminator cycle sequencing kit (Applied Biosystems) and an automatic DNA sequencer (model 373A; Applied Biosystems). The closest known relatives of the new isolates were determined by performing database searches. Closely related sequences were retrieved from EMBL and aligned with the newly determined sequences using the program DNATools (Rasmussen, 1995). The resulting multiple sequence alignment had approximately 100 bases at the $5^{\prime}$ end of the rRNA omitted from further analysis, because of alignment uncertainties due to the highly variable region V1, using the program GeneDoc (Nicholas et al., 1997). A phylogenetic tree was reconstructed according to the neighbour-joining method (Saitou \& Nei, 1987) with the programs DNATools and TreeView (Page, 1996), and the stability of the groupings was estimated by bootstrap analysis (1000 replications).

The unidentified organisms from seals consisted of Gram-positive cocci arranged in pairs or short chains. The organisms were facultatively anaerobic and catalasenegative. They gave a positive reaction in Streptex with Lancefield group C. Using the API Rapid ID 32Strep test system, the unknown seal isolates were relatively unreactive, forming acid from lactose and maltose, and displaying activity for alanine phenylalanine proline arylamidase, alkaline phosphatase and $\beta$-galactosidase; reactions for glycyl trytophan arylamidase, urease and arginine dihydrolase were either weakly positive or negative. All other reactions in the API Rapid ID 32Strep test system were negative. Using the API 20Strep system, both of the strains produced acid from lactose but not from any other carbohydrates in the test gallery. Positive reactions were obtained for alkaline phosphatase and leucine arylamidase; arginine dihydrolase gave variable results. All other enzyme tests were negative. Employing the API ZYM test kit, positive reactions were obtained only for alkaline phosphatase, acid phosphatase (weak), chymotrypsin, leucine arylamidase and valine arylamidase.

The morphological and general biochemical characteristics of the unidentified chain-forming, coccus-shaped isolates from seals were consistent with their tentative assignment to the genus Streptococcus, but they did not correspond to any recognized species. To investigate further their phenotypic resemblance to streptococci, whole-cell protein profiling studies were performed. The two seal isolates were found to possess closely related protein patterns, forming a tight cluster that was distinct from those of all other reference streptococcal species. The nearest neighbours to the unknown species from the PAGE analysis corresponded to Streptococcus porcinus, Streptococcus salivarius and Streptococcus vestibularis, joining the cluster formed by the seal organisms at approximately $60 \%$ similarity (data not shown). 16S rRNA gene sequencing studies were performed to ascertain the phylogenetic affinities of the unidentified Streptococcus-like organisms. The almost-complete gene sequences ( $>1400$ bases) of the two strains were determined; pair-wise analysis revealed
$100 \%$ sequence similarity, indicating that the organisms were genetically highly related. Searches of the GenBank database revealed streptococci to be the nearest phylogenetic relatives of the unidentified isolates. Phylogenetic analysis confirmed the association of the unidentified seal bacterium with the genus Streptococcus, with the unknown bacterium forming a distinct subline. A tree based on a reduced data set showing the nearest phylogenetic relatives of the unknown bacterium is depicted in Fig. 1. The DNA $\mathrm{G}+\mathrm{C}$ content of a representative strain $\left(\mathrm{M} 54 / 01 / 1^{\mathrm{T}}\right)$ of the unknown bacterium was determined to be $38 \mathrm{~mol} \%$.

Comparative 16S rRNA gene sequence analysis unequivocally demonstrated that the unidentified, catalasenegative, coccus-shaped organisms from seals represent a hitherto unknown streptococcal species. Phylogenetically, the unknown bacterium forms a distinct subline within the genus. Although the bacterium (as exemplified by strain M54/01/1 ${ }^{\mathrm{T}}$ ) displayed a loose association with a small subcluster of species (embracing Streptococcus entericus, Streptococcus suis and Streptococcus acidominimus), bootstrap resampling showed that it did not possess a statistically significant association with any recognized species. This strain had a $16 \mathrm{~S}$ rRNA sequence similarity of $94 \%$ with its nearest neighbour S. entericus, an organism isolated from cattle (Vela et al., 2002). Similar levels of sequence divergence $(5-7 \%)$ were also found between the unknown seal bacterium and its other close phylogenetic relatives (Streptococcus hyovaginalis, 93.7\%; Streptococcus pluranimalium, 93.2\%; Streptococcus thoraltensis, 93.9\%; Streptococcus ovis, 93.2\%; Streptococcus minor, $93 \%$; S. suis, $93.6 \%$; S. acidominimus, $94 \cdot 3 \%$ ). Divergence values of $3 \%$ or greater are considered to be strong evidence that organisms are not related at the species level. Support for the distinctiveness of the unknown seal bacterium was also evident from phenotypic analyses. In particular, whole-cell protein profiling, a powerful technique for comparing closely related organisms and which correlates well with results from DNA-DNA hybridization experiments (Vandamme et al., 1996), showed the organisms from seals were phenotypically quite separate from all other streptococcal species. The unidentified seal bacterium also produced very distinct biochemical profiles (API Rapid ID 32Strep numerical profile 4/5 0/4 $01220 / 40$ 0/1 $000 / 2$ and API 20Strep profile $0060 / 1400$ ), which served to distinguish it from all other described streptococcal species. Therefore, based on both phenotypic and phylogenetic criteria, we suggest that the unknown bacterium from seals merits assignment to a novel species within the genus Streptococcus, for which the name Streptococcus marimammalium sp. nov. is proposed. Tests that are useful in distinguishing S. marimammalium from other closely related streptococcal species are shown in Table 1.

\section{Description of Streptococcus marimammalium sp. nov.}

Streptococcus marimammalium (ma.ri.mam.ma'li.um. L. neut. n. mare the sea; N.L. neut. gen. pl. n. mammalium 


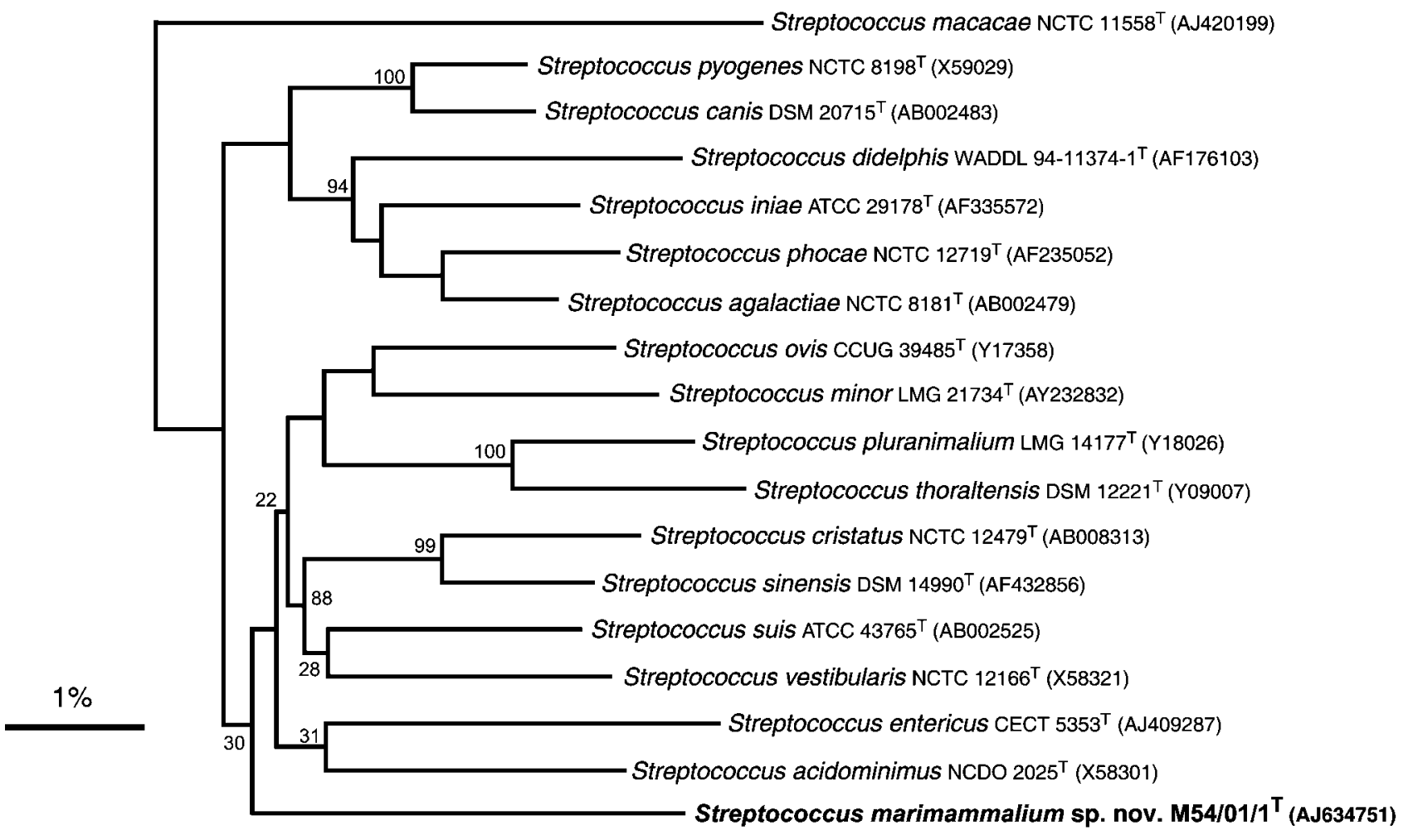

Fig. 1. Unrooted tree based on $16 \mathrm{~S}$ rRNA gene sequence analysis showing the phylogenetic relationships of Streptococcus marimammalium sp. nov. Bar, $1 \%$ sequence divergence.

Table 1. Tests that are useful in distinguishing Streptococcus marimammalium sp. nov. from its closest phylogenetic relatives and some other streptococci from sea mammals

Species: 1, Streptococcus marimammalium sp. nov.; 2, S. entericus; 3, S. acidominimus; 4, S. suis; 5, S. iniae; 6, S. phocae; 7, S. ovis; 8, S. hyovaginalis; 9, S. thoraltensis. Information on Lancefield antigens and haemolytic reactions is from Facklam (2002). +, Positive; -, negative; V, variable; ND, not determined. Biochemical results were obtained from the API Rapid ID 32Strep test system from Collins et al. (2001), Devriese et al. (1997), Vela et al. (2002) and the present study.

\begin{tabular}{|c|c|c|c|c|c|c|c|c|c|}
\hline Characteristic & 1 & 2 & 3 & 4 & 5 & 6 & 7 & 8 & 9 \\
\hline \multicolumn{10}{|l|}{ Acid from: } \\
\hline Cyclodextrin & - & + & - & - & $\mathrm{V}$ & - & $\mathrm{V}$ & - & - \\
\hline Glycogen & - & + & - & + & + & V & + & $\mathrm{V}$ & - \\
\hline Mannitol & - & - & + & - & + & - & + & + & + \\
\hline Ribose & - & - & - & - & + & - & - & $\mathrm{V}$ & + \\
\hline Sorbitol & - & - & - & - & - & - & + & $\mathrm{V}$ & + \\
\hline Sucrose & - & + & + & + & + & - & + & + & + \\
\hline Trehalose & - & + & $\mathrm{V}$ & + & + & - & + & + & + \\
\hline \multicolumn{10}{|l|}{ Production of: } \\
\hline$\beta$-Galactosidase & + & + & + & $\mathrm{V}$ & + & - & $\mathrm{V}$ & $\mathrm{V}$ & - \\
\hline
\end{tabular}


of mammals; N.L. gen. pl. n. marimammalium of marine mammals).

Cells stain Gram-positive and are cocci which occur in pairs or short chains. Non-spore-forming. Colonies are $0 \cdot 2-0.3 \mathrm{~mm}$ in diameter after $24 \mathrm{~h}$ incubation on sheep blood agar, grey-white in colour and non-haemolytic on first isolation, becoming $\beta$-haemolytic after 3 days. No growth occurs on MacConkey agar with or without salt. Lancefield serological group C. Facultatively anaerobic and catalase-negative. Using API test kits, acid is produced from lactose but not from L-arabinose, D-arabitol, cyclodextrin, glycogen, inulin, mannitol, melibiose, melezitose, methyl $\beta$-D-glucopyranoside, pullulan, raffinose, ribose, sorbitol, starch, sucrose, D-tagatose or trehalose; acid may or may not be produced from maltose. Alanine phenylalanine proline arylamidase, acid phosphatase (weak), chymotrypsin, leucine arylamidase and valine arylamidase are produced but activity for cystine arylamidase, $\alpha$-fucosidase, $\alpha$-galactosidase, $\beta$-glucosidase, $\beta$-glucuronidase, lipase C14, $\alpha$-mannosidase, $\quad \beta$-mannosidase, $\quad N$-acetyl- $\beta$ glucosaminidase, pyroglutamic acid arylamidase and trypsin are not detected. Activity for arginine dihydrolase, alkaline phosphatase, $\beta$-galactosidase, urease and glycyl trytophan arylamidase is variable. Aesculin and hippurate are not hydrolysed. Acetoin is not produced.

The type strain, $\mathrm{M} 54 / 01 / 1^{\mathrm{T}} \quad\left(=\mathrm{CCUG} \quad 48494^{\mathrm{T}}=\mathrm{CIP}\right.$ $108309^{\mathrm{T}}$ ), was isolated from a grey seal. Its DNA $\mathrm{G}+\mathrm{C}$ content is $38 \mathrm{~mol} \%$.

\section{Acknowledgements}

We appreciate the help of Kent Molin, Elisabeth Inganäs and Maria Ohlén in performing phenotypic analyses and Nick Davison in providing one of the grey seal samples. Thanks are also given to Tony Patterson and Bob Reid for providing the tissue samples for the common seal isolate. The Scottish Strandings Scheme receives support from the UK Department of the Environment, Farming and Rural Affairs.

\section{References}

Collins, M. D., Hutson, R. A., Hoyles, L., Falsen, E., Nikolaitchouk, N. \& Foster, G. (2001). Streptococcus ovis sp. nov., isolated from sheep. Int J Syst Evol Microbiol 51, 1147-1150.

Devriese, L. A., Pot, B., Vandamme, P., Kersters, K., Collins, M. D., Alvarez, N., Haesebrouck, F. \& Hommez, J. (1997). Streptococcus hyovaginalis sp. nov. and Streptococcus thoraltensis sp. nov., from the genital tract of sows. Int J Syst Bacteriol 47, 1073-1077.

Facklam, R. (2002). What happened to the streptococci: overview of taxonomic and nomenclature changes. Clin Microbiol Rev 15, 613-630.

Lawson, P. A., Foster, G., Falsen, E., Davison, N. \& Collins, M. D. (2004). Streptococcus halichoeri sp. nov., isolated from grey seals (Halichoerus grypus). Int J Syst Evol Microbiol 54, 1753-1756.

Mesbah, M., Premachandran, U. \& Whitman, W. B. (1989). Precise measurement of the $\mathrm{G}+\mathrm{C}$ content of deoxyribonucleic acid by high-performance liquid chromatography. Int J Syst Bacteriol 39, 159-167.

Nicholas, K. B., Nicholas, H. B., Jr \& Deerfield, D. W., II (1997). GeneDoc: analysis and visualization of genetic variation. EMBNEW News 4, 14.

Page, R. D. M. (1996). TreeView: an application to display phylogenetic trees on personal computer. Comput Appl Biosci 12, 357-358.

Pier, G. B. \& Madin, S. H. (1976). Streptococcus iniae sp. nov., a beta-hemolytic streptococcus from an Amazon freshwater dolphin, Inia geoffrensis. Int J Syst Bacteriol 26, 545-553.

Pot, B., Vandamme, P. \& Kersters, K. (1994). Analysis of electrophoretic whole-organism protein fingerprints. In Modern Microbial Methods. Chemical Methods in Prokaryotic Systematics, pp. 493-521. Edited by M. Goodfellow \& A. G. O'Donnell. Chichester: Wiley.

Rasmussen, S. W. (1995). DNATools, a software package for DNA sequence analysis. Copenhagen: Carlsberg Laboratory.

Saitou, N. \& Nei, M. (1987). The neighbor-joining method: a new method for reconstructing phylogenetic trees. Mol Biol Evol 4, 406-425.

Skaar, L., Gaustad, P., Tonjum, T., Holm, B. \& Stenwig, H. (1994). Streptococcus phocae sp. nov., a new species isolated from clinical specimens of seals. Int J Syst Bacteriol 44, 646-650.

Vandamme, P., Pot, B., Gillis, M., DeVos, P., Kersters, K. \& Swings, J. (1996). Polyphasic taxonomy, a consensus approach to bacterial systematics. Microbiol Rev 60, 407-438.

Vandamme, P., Torck, U., Falsen, E., Pot, B., Goossens, H. \& Kersters, K. (1998). Whole-cell protein electrophoretic analysis of viridans streptococci: evidence for heterogeneity among Streptococcus mitis biovars. Int J Syst Bacteriol 48, 117-125.

Vela, A. I., Fernández, E., Lawson, P. A., Latre, M. V., Falsen, E., Domínguez, L., Collins, M. D. \& Fernández-Garayzábal, J. F. (2002). Streptococcus entericus sp. nov., isolated from cattle intestine. Int J Syst Evol Microbiol 52, 665-669.

Weinstein, M. R., Litt, M., Kertesz, D. A. \& 9 other authors (1997). Invasive infections due to a fish pathogen, Streptococcus iniae. N Engl J Med 337, 589-594. 